\title{
RELATIONSHIP OF DEMOGRAPHY, SOCIO-ECONOMY, AND HUSBAND'S SUPPORT WITH THE USE OF MEDICAL OPERATIVE FOR WOMEN CONTRACEPTIVES (TUBECTOMY) TOWARDS COUPLE OF CHILDBEARING AGE IN PUSKESMAS MOJO SURABAYA
}

\author{
Surya Doni ${ }^{1}$, Lutfi Agus Salim ${ }^{2}$ \\ ${ }^{1,2}$ Department of Biostatistics and Population, Faculty of Public Health, Universitas Airlangga, 60115 Surabaya, \\ East Java, Indonesia \\ Corresponding Author: Surya Doni \\ E-mail: suryadoni567@gmail.com
}

\begin{abstract}
The family planning program has a very appropriate role in addressing population growth. Most family planning participants chose injections and pills, while medical operative for women contraceptives (tubectomy) and medical operative for men (vasectomy) are the least preferrable. Based on National Board of Population and Family Planning data 2017, the majority of new family planning participants in Indonesia are dominated by family planning participants who use non-long-term contraception methods by $79.48 \%$ of all new family planning participants. The use of long-term contraceptive methods from year to year has increased compared to non-longterm contraceptive methods, but there is more interest in acceptors to use non-long-term contraceptive methods. The research objective is to examine the relationship between demographics, socio-economics, husband's support, and the use of medical operative for women contraceptives device (tubectomy). The research type is inferential research with cross-sectional design. The sample in this study was 40 EFAs, of which 20 EFAs used medical operative for women contraceptives (tubectomy), and 20 couples of childbearing age used non-medical operative for women contraceptives (tubectomy). The study results showed that the level of education, age, income, and husbands' motivation are not related to the use of medical operative for women contraceptives (tubectomy). However, the number of children is related to the use of medical operative for women contraceptives (tubectomy). The researcher's suggestion is to conduct education-related for pregnancy management so that the people can estimate the number of children, the distance of pregnancy, and the risk of pregnancy.
\end{abstract}

Keywords: demographics, socio-economy, husband's support, use of contraception

\begin{abstract}
ABSTRAK
Program keluarga berencana mempunyai possi yang sangat tepat dalam mengatasi pertumbuhan penduduk. Sebagian besar peserta KB memilih suntik dan pil, sedangkan yang paling sedikit digunakan MOW dan MOP. Data BKKBN tahun 2017 di Indonesia mayoritas peserta KB baru didominasi oleh peserta KB yang menggunakan non-metode kontrasepsi jangka panjang (non-MKJP) sebesar 79,48\% dari seluruh peserta KB baru. Pemakaian MKJP dari tahun ke tahun terjadi peningkatan dari pada non-MKJP tetapi minat akseptor untuk memakai nonMKJP lebih banyak. Tujuan penelitian yakni mengkaji hubungan antara demografi, sosial ekonomi, dukungan suami dengan pemakaian alat kontrasepsi KB MOW. Jenis penelitian inferensial dengan desain cross sectional. Sampel dalam penelitian ini sebanyak 40 PUS, dimana 20 PUS menggunakan MOW dan 20 pasangan usia subur menggunakan non-MOW. Hasil penelitian yaitu tingkat pendidikan, umur, tingkat pendapatan, dan motivasi suami tidak berhubungan dengan pemakaian alat kontrasepsi MOW. Namun, jumlah anak berhubungan dengan pemakaian alat kontrasepsi MOW. Saran peneliti yaitu melakukan edukasi terkait mengelola kehamilan sehingga masyarakat mampu memperkirakan jumlah anak, jarak kehamilan, dan risiko kehamilan.
\end{abstract}

Kata kunci: demografi, sosial ekonomi, dukungan suami, pemakaian alat kontrasepsi

\section{INTRODUCTION}

Population is one of the problems currently faced by Indonesia. One of the government's efforts to overcome population problem is by carrying out family planning program. This is the form of program that is expected to be able to increase society's awareness about age of marriage, to improve the welfare of happy and 
prosperous nuclear families and to increase knowledge on fostering family security (Indonesian Ministry of Health, 2016).

The Family Planning Program is a strategic effort to overcome the population growth rate. Family planning program can reduce economic problems in nuclear families, families in general, and society. In addition to economics, married couples must also be possessed in choosing what contraception will be used so that they can manage the wanted pregnancy. The family planning program also provides economic benefits to couples, families, and society. This financial benefit is what makes the family planning program work as the main program to improve the survival of mothers, infants, and healthy children (Mulyana, 2019).

Couples of Childbearing Age are divided into two types of participants: new family planning participants and active family planning participants. After fertility, participants who still use active birth control are women who use birth control without interspersed with pregnancy (Rahayu, Nugroho, and Winarni, 2013). The types of contraception that are currently often used by the public, namely injections and pills, have been chosen by many active and new birth control participants. In contrast, a medical operative for women contraceptives (tubectomy) and medical operative for men (vasectomy) are the least popular methods of contraception because they are difficult to install and cannot return to normal (National Board of Population and Family Planning, 2017).

The use of non-long-term contraceptive methods (non-tubectomy) in Indonesia is mostly done by new family planning participants at $79.48 \%$. In comparison, the longterm contraceptive methods of all new family planning participants are $20.51 \%$ (National Board of Population and Family Planning, 2017). The achievements of family planning participants that use non-long-term contraceptives are dominated by injections users since this method is relatively affordable, while the use of long-term contraceptives tend to be more expensive including the installation fee..

Based on 2016 data, the percentage of using active birth control for child bearing age couples in Indonesia is $74.8 \%$. The users or contraceptives' acceptors can be distinguished into long-term contraceptive methods and nonlong-term contraceptive methods. Family planning participants using long-term contraceptive methods such as IUD of $10.61 \%$, implants of $11.20 \%$, a medical operative for women contraceptives (tubectomy) of 3.54\%, and medical operative for men (vasectomy) of $0.64 \%$. Non-long-term contraceptive methods such as injections of $47.96 \%$, pills of $22.81 \%$, and condoms of $3.23 \%$ (Nasional Board of Population and Family Planning, 2017).

The use of long-term contraceptive methods in 2015-2017 namely IUD, implants, medical operative for women contraceptives (tubectomy), and medical operative for men (vasectomy) in Surabaya has changed. In 2015 the number of long-term contraceptive methods users was 63,500 people $(16.2 \%), 60,593$ people $(16.6 \%)$ in 2016 , and 62,455 people (16.6\%) in 2017. In 2015-2017 there was a change in non-long-term contraceptives, including condoms, injections, and pills. In 2015 the number of non-long-term contraceptive methods users was 328,628 people (83.8\%). In 2016 there was a decrease in 305,277 users (83.4\%). In 2017 there was an increase of 313,862 people ( $83.4 \%$ ). The use of long-term contraceptive methods in 2015-2017 has increased compared to non-long-term contraceptive methods, but the acceptors' interest for those who use non-long-term contraceptive methods is still higher compared to the long-term contraceptive methods.

Data from the Surabaya City Health Office showed that the number of active family planning participants in Puskesmas Mojo in 2017 was 10,293 acceptors, with IUD users as many as 2,320 people $(22.5 \%)$, medical operative for women contraceptives (tubectomy) users as many as 907 people (8.8\%), medical operative for men (vasectomy) users as many as 4 people $(0.01 \%)$, implants users 350 people (3.4\%), injections users 5,105 people (49.65), pills users 1,422 people $(13.8 \%)$ and condoms users 185 people (1.8\%). Injections is the most used contraceptives followed by pills. This data showed that the use of non-long-term contraceptive methods is still high compared to long-term contraceptive methods. The low number of medical operative for women contraceptives (tubectomy) participants are found at Puskesmas Mojo (Surabaya City Health Office, 2017).

One of the factors that influence the use of contraceptives is husbands' support. Based on the research conducted by Lismawati (2018), there is a significant relationship between the 
husband's support and the use of IUD. This relationship is in line with Andini (2017) which stated that there is an attachment between husband's motivation and the decision of using long-term contraception in 2017 around Puskesmas Sleman in Yogyakarta region.

According to the description, the researcher is interested in studying the demography, socio-economy, and husbands' support for the use of medical operative for women contraceptives (tubectomy) to EFA in Puskesmas Mojo, Surabaya.

\section{METHODS}

This research used a quantitative approach with a cross-sectional design. The analysis was carried out at Puskesmas Mojo in Surabaya.The sample in this study was 40 couples of childbearing age, of which 20 couples used tubectomy, and 20 couples used nontubectomy. The Independent variables in this study are the characteristics of respondents and the husbands' support. Respondent characteristics in question include education level, age, total income, and the number of children. The husbands' support variable provides information, emotional, instrumental, and appreciation support. The dependent variable in this study is the use of tubectomy contraceptive. In this research, data collection was carried out through interviews with questionnaires distributed to each of the respondents' house.

This research has been conducted beforehand to test ethics to ensure that respondents are not abused, and ethical testing is also useful to ensure there are no injured parties in the study. Ethics approval was obtained from FKG UNAIR with reference number 610/HRECC.FODM/IX/ 2019.

\section{RESULT}

\section{Overview of Puskesmas Mojo in Surabaya}

Puskesmas Mojo is located in the middle of the eastern city of Surabaya and is very strategic. The working area of Puskesmas Mojo is $\pm 4.36 \mathrm{~km}^{2}$. Puskesmas Mojo is located in Mojo Klanggru, Gubeng and is divided into 3 sub-districts, namely Mojo, Airlangga and Gubeng. The Mojo Community Health Work Center includes 44 Posyandu in 12 RW.

\section{Overview of Respondents' Demographic Characteristics}

Characteristics of respondents interviewed were divided into two age categories, namely the age group at risk and the age group with no risk, the educational status was divided into two namely low and high level of education, low and high family income, and family with one or two children is low and more than two is high. Table 1 can be seen in the description of respondents' demographic characteristics.

Table 1. Demographic Characteristics of Respondents Using Non-tubectomy and Tubecomy in Puskesmas Mojo in 2020

\begin{tabular}{lcccc}
\hline \multirow{2}{*}{ Characteristics } & \multicolumn{2}{c}{$\begin{array}{c}\text { Non- } \\
\text { Tubectomy }\end{array}$} & \multicolumn{2}{c}{ Tubectomy } \\
\cline { 2 - 5 } & f & $\%$ & f & \% \\
\hline Age & & & & \\
\hline At Risk & 10 & 50 & 8 & 40 \\
No Risk & 10 & 50 & 12 & 60 \\
\hline Education & & & & \\
\hline < High school & 4 & 20 & 6 & 30 \\
> High school & 16 & 80 & 14 & 70 \\
\hline Income & & & & \\
\hline Low & 14 & 70 & 16 & 80 \\
High & 6 & 30 & 4 & 20 \\
\hline Number of Children & & & \\
\hline$\leq 2$ Children & 13 & 65 & 3 & 15 \\
$>2$ children & 7 & 35 & 17 & 85 \\
\hline
\end{tabular}

In Table 1, it can be explained that respondents who did not use tubectomy in the age category at risk were 10 people $(50 \%)$, and 10 people $(50 \%)$ were not at risk. Whereas respondents who used tubectomy in at risk age group were 8 people (40\%) and 12 people $(60 \%)$ were not at risk.

Respondents who did not understand tubectomy and had a low income were 14 respondents $(70 \%)$. The small portion has above the average income of 6 respondents (30\%). The education in the group that did not use tubectomy was mostly highly educated, with a total of 16 people (80\%). A small portion has low income above the average number of 4 respondents $(20 \%)$.

Many of 13 people did not use tubectomy and had children fewer than two (65\%). Respondents who have more than two children are 7 people $(35 \%)$. Respondents who used 
tubectomy and had less than two children are 17 respondents $(85 \%)$.

\section{Overview of Husbands' Support}

The husbands' support symbolize a display of relationships between individuals present in matters that provide emotional benefits and influence the acceptors. The respondents husbands' support was identified by emotional, instrumental, informative, and appreciative support. Each indicator of husbands' support will be grouped into two groups, namely not supported and supported. The following is the frequency distribution of husbands' support felt by the respondents.

Table 2. Frequency Distribution of Husbands' Support Perceived by the Respondents

\begin{tabular}{lcccc}
\hline \multirow{2}{*}{$\begin{array}{c}\text { Husbands' } \\
\text { Support }\end{array}$} & \multicolumn{2}{c}{$\begin{array}{c}\text { Non- } \\
\text { Tubectomy }\end{array}$} & \multicolumn{2}{c}{ Tubectomy } \\
\cline { 2 - 5 } & $\mathbf{f}$ & $\mathbf{\%}$ & $\mathbf{f}$ & $\%$ \\
\hline Emotional Support & & & \\
\hline Not supported & 8 & 40 & 7 & 35 \\
Supported & 12 & 60 & 13 & 65 \\
\hline Instrumental Support & & & \\
\hline Not supported & 3 & 15 & 6 & 30 \\
Supported & 17 & 85 & 14 & 70 \\
\hline Informative Support & & & \\
\hline Not supported & 10 & 50 & 11 & 55 \\
Supported & 10 & 50 & 9 & 45 \\
\hline Appreciative Support & & & \\
\hline Not supported & 3 & 15 & 3 & 15 \\
Supported & 17 & 83 & 17 & 85 \\
\hline
\end{tabular}

Based on Table 2, it can be said that 8 people (40\%) did not use tubectomy and did not receive emotional support from their husbands. 12 respondents $(60 \%)$ received emotional support from their husbands. Respondents who used tubectomy and did not get emotional support from their husbands were 7 people (35\%), and those who received emotional support from their husbands were 13 people $(65 \%)$.
Respondents who did not use tubectomy and did not receive instrumental support from their husbands were 3 people (15\%), and those who received informative support from their husbands were 17 people (85\%). Respondents who used tubectomy and did not get instrumental support from their husbands were 6 people $(30 \%)$, and those who received informative support from husbands were 14 people $(70 \%)$.

Respondents who did not use tubectomy and did not get information support from their husbands were 10 people (50\%), and those who received informative support from their husbands were 10 people (50\%). Respondents who used tubectomy and did not get informative support from their husbands were 11 people (55\%), and those who received informative support from their husbands were 9 people $(45 \%)$.

Respondents who did not use tubectomy and did not receive appreciative support from the husband were 3 people $(15 \%)$ and who received support from the husband as many as 17 people (85\%). Respondents who used tubectomy and did not receive appreciative support from the husbands were 3 people (15\%) and received appreciative support from the husbands were 17 people ( $85 \%)$.

\section{Relationship between Respondents' Characteristics and the Use of Medical Operative for Women Contraceptives (Tubectomy)}

The results of the analysis of the relationship of respondents' characteristics with the use tubectomy can be seen in Table 3 . Table 3 explains that there are 3 variables that are not related namely educational variables $(\mathrm{p}=$ $0.465)$, income variables $(\mathrm{p}=0.465)$ and age variables $(\mathrm{p}=0.525)$. However, the number of children ( $\mathrm{p}$-value $=0.001)$ means that the number of living children is related to the use of tubectomy.

Table 3. Relationship between Respondents' Characteristics and the Use of Medical Operative for Women Contraceptives (Tubectomy)

\begin{tabular}{lccc}
\hline Independent Variables & Dependent Variables & P. & Information \\
\hline Age & & 0.525 & Not related \\
Education & Use of Tubectomy & 0.465 & Not related \\
Income & & 0.465 & Not related \\
Number of children & & 0.001 & Related \\
\hline
\end{tabular}


Table 4. The Relationship Between Husbands' Support and the Use of Medical Operative for Women Contraceptives (Tubectomy)

\begin{tabular}{lccc}
\hline Independent Variable & Dependent Variable & P. & Information \\
\hline Emotional Support & & 0.744 & Meaningless \\
Instrumental Support & Use of Tubectomy & 0.451 & Meaningless \\
Informative Support & & 0.752 & Meaningless \\
Appreciative Support & & 1.000 & Meaningless \\
\hline
\end{tabular}

\section{The Relationship Between Husbands' Support and the Use of Medical Operative for Women Contraceptives (Tubectomy)}

Table 4 shows that all components in the husbands' support variable do not affect the use of tubectomy and is proven by a p-value of more than 0.05 .

\section{DISCUSSION}

\section{Relationship of Respondents' Characteristics with the Use of Medical Operative for Women Contraceptives (Tubectomy) and Non-Medical Operative for Women Contraceptives (Non-Tubectomy)}

In this research, the relationship between demographic characteristics and the use of tubectomy and non-tubectomy was analyzed using the Chi-Square test. The results of the research test explain that the number of children has a significant relationship to the use of tubectomy while the other variables of respondents' characteristics are not significantly related.

The respondents' age has no relationship with the use of tubectomy and non-tubectomy. This result shows that there is no relationship between the age groups of respondents who are at risk or not at risk with the decision making of respondents regarding the use of contraceptives, both tubectomy and non-tubectomy. Research by Setiawati, Yanti, and Pasaribu (2019) support this result, stating that the age for women of childbearing age was not related to long-term contraceptive methods usage in the working area of Puskesmas Rengasdengklok. The research conducted by Setiawati, Yanti and Pasaribu had the same results as Sari and Yulnefia (2019). The result stated that age does not affect the choice of IUD contraception. Age is not related to the use tubectomy because most respondents have chosen other types of contraceptives that are more comfortable and affordable. Respondents did not feel the need to switch to more effective contraceptives despite receiving counseling by health workers.

Respondents' education has no relationship with the use of both tubectomy and nontubectomy. This observation is in line with research by Irawati (2017), which stated that women's education does not influence the decision to use an IUD contraception since in the decision-making process, the mother must also consider the husbands' opinion. Also, in line with research by Grestasari (2014), other research results said that the mothers' level of knowledge does not affect the choice of contraception type because the level of education does not determine one's consciousness. After all, learning can be obtained through experience or counseling from experts. The level of education does not affect the use of tubectomy or non-tubectomy since the level of education does not determine the mother's knowledge. Furthermore, the consideration to choose contraceptives is also influenced by several other factors such as advice given by health workers and mothers' ability.

Income level does not affect the use of tubectomy and non-tubectomy because a highincome level does not necessarily change the understanding of the effectiveness of the contraception and does not guarantee the choice of contraception. This observation is in line with Adiputra et al. (2016) which stated that there is no relationship between EFA income and the choice of injections contraceptives. In line with research by Aryati, Sukamdi, and Widyastuti (2019), the level of income is not related to contraceptives.

There is characteristics difference for number of children in the use of tubectomy and non-tubectomy, respectively, having children more than two and fewer than two. This shows that there is a significant relationship between number of children with the use of tubectomy 
and non-tubectomy. This is in line with research by Rizkitama (2017) which stated that respondents with children have participated in using tubectomy $(p=0.026)$. Moreover, it is also supported by Arliana, Sarake, and Seweng (2013) which stated that there is meaningful relationship between the number of children and the use of hormonal contraceptives with $\mathrm{P}$ $=0.031$. The significant relationship is caused by the differences in the use of tubectomy and non-tubectomy which resulted in number of children differences.

\section{Relationship between Husbands' Support and the Use of Tubectomy and Non- Tubectomy}

From this research, it can be concluded that there are four components in husbands' support variables namely emotional support, instrumental support, informative support, and appreciative support all of them which are not related to the use of tubectomy and nontubectomy. The results of the research are in line with research carried out by Mularsih, Munawaroh, and Elliana (2018) mentioned that the husbands' support did not affect the use of IUD. The results of this research are equivalent to the research conducted by Mariati (2018) that the husbands' support is not related to the selection of the use of the IUD in Plumbon village.

This study results contradict Hidayah and Lubis (2019) study, which stated that the husbands' motivation is related to the use of tubectomy in Puskesmas Simomulyo. It also contradicts the research by Pinamangun, Kundre, and Bataha (2018), which stated that the husbands' support felt by respondents is good, the selection of the type of IUD in the working area of Puskesmas Makalehi in West Siau was related to the husbands' support.

After the interview, the reason for the lack of husbands' support, the doctor suggested after the operation to give birth to the 3rd child, tubectomy should be done to prevent further pregnancy, and the agreement is done without asking the husbands' opinions first.

Decision making on the majority use of contraception does not require advice or encouragement from the husbands. This fact is because there is an increase in women's education in the global era and the high level of awareness on the importance of contraception so that they can make their own decisions.

\section{CONCLUSIONS AND SUGGESTIONS}

\section{Conclusion}

This study concludes that some respondents are in the no-risk age group, highly educated, have low incomes, and have children aged more than two years old. Some respondents felt that their husbands' support was commendable.

After administering the chi-square test, it was found that age, education level, and income level variables are not related to the use of tubectomy. The number of children is associated with the use of tubectomy, although the husbands' support is not related to the use of tubectomy.

\section{Suggestion}

Related to the problems that exist in this researcher, it is suggested to develop information media to improve counseling in the context of contraceptives observers that are right for the society. Conduct education related to pregnancy management so that the society can estimate the number of children, the distance of pregnancy, and the risk of pregnancy.

\section{REFERENCES}

Adiputra, R., Nugroho, D., Winarni, S. and Dharminto, 2016. Hubungan Beberapa Faktor pada Wanita PUS dengan Keikutsertaan KB Suntik di Desa Duren Kecamatan Sumowono Kabupaten Semarang. Jurnal Kesehatan Masyarakat, 4(3), pp.18-25.

Andini, I.C., 2017. Hubungan Dukungan Suami dengan Pemilihan Kontrasepsi IUD di Puskesmas Tempel 1 Sleman Yogyakarta. Universitas 'Aisyiyah Yogyakarta.

Arliana, W.O.D., Sarake, M. and Seweng, A., 2013. Faktor yang Berhubungan dengan Penggunaan Metode Kontrasepsi Hormonal pada Akseptor KB di Keurahan Pasarwojo Kecamatan Pasarwojo Kabupaten Buton Sulawesi Tenggara. Universitas Hasanudin.

Aryati, S., Sukamdi and Widyastuti, D., 2019. Indikator-Indikator yang dapat Memotivasi Pemakaian Metode Kontrasepsi (Permasalahan di Wilayah Seberang Kota Palembang). Majalah Geografi Indonesia, 33(1), pp.79-85. 
Grestasari, L.E., 2014. Hubungan antara Tingkat Pendidikan, Pengetahuan, dan Usia Ibu PUS dengan Pemilihan Jenis Kontrasepsi di Desa Jetak Kecamatan Sidoharjo Kabupaten Sragen. Universitas Muhammadiyah Surakarta.

Hidayah, N. and Lubis, N., 2019. Hubungan Pengetahuan dan Dukungan Suami terhadap Pemilihan Kontrasepsi Tubektomi. Jurnal Endurance: Kajian Ilmiah Problema Kesehatan, 4(2), pp.421428.

Irawati, D., 2017. Faktor-Faktor yang Mengajak Menggunakan Kontrasepsi IUD (Intra Uterine Device) di Desa Karangjeruk Jatirejo Mojokerto. Medica Majapahit, 9(2), pp.126-141.

Indonesian Ministry of Health, 2016. Buku Kesehatan Ibu dan Anak. Jakarta: Indonesian Ministry of Health.

Lismawati, 2018. Hubungan Pendidikan, Sikap PUS dan Motivasi Suami terhadap Pemakaian Alkon IUD pada Tahun 2017 di Wilayah Kerja Puskesmas Yaman Kota Jambi. Sientia Journal Universitas Adiwangsa Jambi, 7(1), pp.58-64.

Mariati, T., 2018. Pemilihan Pengunaan Kontrasepsi terhadap Dukungan Suami (IUD). Manajemen Kesehatan Yayasan RS. Dr. Soetomo, 4(2), pp.89-109.

Mularsih, S., Munawaroh, L. and Elliana, D., 2018. Hubungan Pengetahuan dan Dukungan Suami dengan Pemilihan Alat Kontrasepsi dalam Rahim (AKDR) pada Pasangan Usia Subur (PUS) di Kelurahan Purwoyoso Kecamatan Ngaliyan Kota Semarang. Jurnal Kebidanan, 7(2), pp.144-154.

Mulyana, 2019. Pemberdayaan Perempuan Melalui Program Keluarga Berencana. Prosiding KS: Riset dan PKM, 4(1), pp.1140.
National Board of Population and Family Planning, 2017. Survei Demografi dan Kesehatan Indonesia. Jakarta: National Board of Population and Family Planning.

Pinamangun, W., Kundre, R. and Bataha, Y., 2018. Hubungan Dukungan Suami dengan Pemilihan Jenis Kontrasepsi Intra Uterine Device pada Wanita Usia Subur di Puskesmas Makalehi Kecamatan Siau Barat. e-Joournal Keperawatan, 6(2), pp.1-7.

Rahayu, I., Nugroho, R.D. and Winarni, S., 2013. Hubungan Beberapa Karakteristik Wanita Pasangan Usia Subur (PUS) Pesera KB Aktif dengan Pemilihan Metode Kontrasepsi Suntik di Kelurahan Kramas Kecamatan Tembalang Triwulan I Tahun 2013. Jurnal Kesehatan Masyarakat Universitas DIponegoro, pp.1-8.

Rizkitama, A.A., 2017. Beberapa Faktor yang Berhubungan dengan Partisipasi Wanita dalam Pemilihan Tubejtomi pada Peserta MJKP di Kecamatan Bumiayu Kabupaten Brebes. Universitas Diponegoro.

Sari, T.W. and Yulnefia, 2019. Penggunaan KB dalam Rahim Berhubungan dengan Faktor Demografi pada Wanita Usia Subur di Puskesmas Payung Sekaki Kota Pekanbaru. Collaborative Medical Journal, 2(1).

Setiawati, R., Yanti, I. and Pasaribu, I.H., 2019. Hubungan Usia Paritas, pendidikan, Sumber Informasi dan Persepsi terhadap Kemauan Wanita Usia Subur Memakai Metode Kontrasepsi Jangka Panjang. Jurnal Singaerbangsa Karawang, 4(1), pp.94-102.

Surabaya City Health Office, 2017. Profil Dinas Kesehatan Kota Surabaya. Surabaya: Surabaya City Health Office. 